\title{
Virtual worlds and social and educational inclusion: case study at Secondary Education Institute Cal Gravat
}

\author{
Linda Castañeda Quintero ${ }^{1 *}$, María del Mar Román García², Ramón Barlam \\ Aspasch $^{3}$ \\ 1University of Murcia, Educational Technology Research Group, Spain \{lindacq@um.es\} \\ 2University of Murcia, Educational Technology Research Group, Spain \{mariamar.roman@um.es\} \\ ${ }^{3}$ Cal Gravat Secondary Education Institute, Spain \{ramon.barlam@gmail.com\} \\ Received on 17 October 2014; revised on 17 October 2014; accepted on 19 January 2015; in press on 15 April 2015 ; published on 15 \\ July 2015 \\ DOI: 10.7821/naer.2015.4.99
}

\begin{abstract}
This article presents a case study with the goal of becoming familiar with and understanding the incorporation of one virtual learning world -Espurnik- in a curricular diversification classroom with students in a situation of educational exclusion or academic failure. This investigation was carried out from an interpretive paradigm with a qualitative methodology grounded in the Case Studies. The data was collected using different qualitative techniques: documentary analysis, direct observation in the virtual world, semi-structured interview with the teacher, and group interview with the students. The conclusions indicate that the emphasis must not be placed on technologies, but rather on the methodological change that many of them foster, setting up the student not a consumer of information but rather a creator and producer of knowledge in a context of collaborative work, attending comprehensively to the community context of the students' educational development.
\end{abstract}

KEYWORDS: ACADEMIC FAILURE, EDUCATIONAL EXCLUSION, EDUCATIONAL TECHNOLOGY, CASE STUDY, VIRTUAL WORLDS.

\section{INTRODUCTION}

In recent years we are experiencing a clear rise in the use of new technologies in the educational environment as well as a proliferation of research in this regard that questions whether the ways of doing things are really changing, or whether those technologies are simply being incorporated without adding anything to what was habitually being done (Boza \& Toscano, 2011). From this research perspective, it is increasingly essential to tackle in-depth analyses of educational realities that allow us to find out the characteristics, possibilities and limitations of the different supposedly innovative educational actions undertaken in the classrooms, in such a way that allows us to carry out prospective studies on the possibilities of one methodology or another, tools, or strategies in a specific educational context.

In this framework, the goal of the paper presented below is a

\footnotetext{
*To whom correspondence should be addressed:

Universidad de Murcia

Facultad de Educación, Campus de Espinardo

Departamento de Didáctica y Organización Escolar

30100 Murcia, Spain
}

description and in-depth analysis of the teaching practices of a secondary teacher that makes use of information and communications technologies (hereinafter ICT), and specifically of virtual worlds (Espurnik), in a curricular diversification classroom with students experiencing a situation of educational exclusion or academic failure.

\section{THEORETICAL FRAMEWORK}

It is undeniable what the technological revolution-understood as mass access to ICT- has meant in the field of education, and what some administrations and teachers have had to design and develop in order to respond to the challenges of a new school in terms of resource provision, teaching orientations, teacher training, diversity, etc. (Sola \& Murillo, 2011; Koh \& Chai, 2014). However, it is vital to value ICT as instruments that help us encourage a change in the educational system in terms of didactics, methodology, classroom organization, and curriculu. (Krajka \& Kleban, 2014; Martínez \& Prendes, 2004). That is, understanding the use of tools as triggers for the transformation of educational contexts in order to make them much more inclusive, "thereby becoming an instrument that allows for the optimization of educational attention to the diversity of the student” (García \& López, 2012, p. 278).

Academic failure is a social reality that is created in and by the school (Escudero, 2005; Spruyt, 2014) and is applied to those students that do not achieve the established results over the course of their academic trajectory. However, its repercussions are not limited to the academic environment, and as indicated by the European Commission (2011), its consequences range from a reduction of opportunities in terms of participation in the different dimensions of the society, to an increase in experiencing situations of social exclusion (Carson, Esbensen, \& Taylor, 2013; Lingard, Hayes, \& Mills, 2003).

Due to the long-term impact of the academic failure on society, there is a broad range of literature about it (Calero, Escardíbul \& Choi, 2012; Escudero, González, \& Martínez, 2009; Fernández, 2010; González, \& Porto 2011; Marchesi, 2003; Martínez, 2009; Navarrete, 2007; Reynolds, 2010, among others), although it appears difficult to reach a consensus on a definition, its causes, or even a solution that could help reduce its occurrence in our school system and thereby in our society. Nevertheless, it is evident that there is a current tendency 
towards using explanatory ecological models in order to comprehend academic failure (Escudero, 2005), which aim to substitute for other too simplistic traditional explanatory models that focusing on a single cause

This ecological perspective must lead us to consider proposals and actions under the cloak of a more inclusive and equitable school (Field, Kuczera, \& Pont, 2007; Walkey, McClure, Meyer, \& Weir, 2013), it allows us to understand the factors and dynamics that begin the failure, as well as offering a resounding answer to why it should not be permitted (Escudero, 2005; Hill, 2014), understanding that we need explanations at different levels "that combine the micro or interpersonal aspects that occur in the classroom and the macro socioeconomic aspects that take into account social, structural and cultural factors" (Abajo, 2011, p. 74).

Curricular Diversification ${ }^{\mathrm{i}}$ is a measure aimed at fighting academic failure, with principles based on attending to the diversity of the student body by implementing diversifications to the curriculum that allow certain students to be able to achieve the goals of Compulsory Secondary Education (and to obtain a diploma). In order to do this, there is a clear need for changes to the teaching methods, contents organization, practical activities, courses, etc.

In that framework, the implementation of ICT in Diversification classrooms is very interesting, especially when that implementation is understood as beyond the mere technical provisions that many institutional programs take into account, but rather as a set of measures for a truly pedagogical implementation and relevant use of those technologies, so that they serve as catalysts for the revision, reconstruction, design, development, and authentic assessment of the curriculum; in short, for provoking profound changes in the entire organization and curriculum design (García \& Cotrina, 2004).

Thus, working in -and with- virtual worlds in the curricular framework is not just another alternative supported by the "innovative" component enjoyed by "new" technologies today (McKinney, Horspool, Safie, \& Richin, 2009), but rather their use in the classroom -by virture of the characteristics inherent in that environment-, offers certain potential advantages.

Wang and Hsu, in their 2009 paper, and Bignell and Parsons (2010) in their paper on good practices for teaching with virtual worlds, cited, among the advantages of using these media, asynchronous learning, the recreational component, the possibility of forming a safe, highly personalizable learning environment, with characteristics that foster the execution of authentic activities. In addition, these and other authors highlight the conditions that foster the development of creativity, exploration, problem solving, construction of shared meaning and collaborative work; as well as improvement in the relations and communications processes (interactivity) and the fact that they can become online workspaces for teachers.

\section{METHODOLOGY}

\subsection{Case Study}

The participants in this case study were the teacher and students of the open classroom at IES Cal Gravat in Manresa, $4^{\text {th }}$ year of ESO [Enseñanza Secundaria Obligatoria (Compulsory Secondary Education)], for the 2013-2014 school year, in which period the data was collected. This group works in one of the islands within the Espurnik virtual world, a virtual world of the Espurna project.
Espurna is a multidisciplinary project, an initiative of the Instituto de las Ciencias de la Education [Institute of Educational Sciences] (ICE) at the Autonomous University of Barcelona, aimed at teachers of pre-school, primary and secondary education. Espurna understands learning as an opportunity for everyone, that takes advantage of diversity for building a framework of convivence and integral learning, both in curricular diversification classrooms as well as in ordinary classrooms.

Currently, Espurna includes more than 10,000 participants between teachers and students, and it has a team of about 50 people. Thanks to the networking work of all involved, other teachers can find examples of good methodologies, activities, and dynamics aimed at a qualitative improvement to the school. All of those proposals, which appear monthly online, are the result of a collaboration among its members, and the activities involved are created from the perspective of multiple intelligences and the achievement of basic competencies.

It is understood that this project represents an authentic professional learning community, strengthened by the development of new technologies (Rodríguez-Mena \& García, 2003), and that in there takes place a training model focused on practice, on the exchange of concrete experiences, and that it requires the active and committed participation of its members (Escudero, 2009b), and that its clear objective is to improve the learning processes of all its participants.

Espurnik, on the other hand, is the virtual world that the Espurna project uses. It is a specialized Open Sim installation (http://opensimulator.org/wiki/Main_Page) serving the schools involved in Espurna.

Within this virtual world, students and teachers create their avatars and have their own workspaces (buildings) in a virtual archipelago full of islands. Each school participating in the project has its own island, sharing only one of those as a common workspace that includes exhibition halls, auditorium, media library, etc.

Some of the activities developed by the teachers in Espurnik include different curricular areas, virtual exhibitions with panels created online, small-group activities, virtual reconstructions of familiar realities, and panels developed by the students themselves in order to learn basic concepts (e.g. vocabulary).

In order to facilitate teaching staff access, training activities are carried out from Espurna (usually with a pyramid training model) in order for the teaching staff to become accustomed to the environment and to discover the pedagogical possibilities it offers. Not in vain this is a space that lends itself to experimentation and the exchange of experiences.

All the activities have an explanatory panel so that both students and teachers can access them (Barlam, Lasala, Masalles, \& Pinya, 2011).

\subsection{Methodology}

In this framework of action, this study aims to figure out and comprehend the incorporation of the Espurnik -as a virtual world of learning- into a specific curricular diversification classroom, with students in a situation of educational exclusion or academic failure.

The paradigm sustaining the research is the interpretive paradigm and a qualitative methodology is used based on the Case Studies, since the study's priority is to find answers to a particular situation, without looking to generalize the results (Koetting, 1984; Merrian, 1988; Stake, 1995; Yin, 1994).

From this perspective, the analysis will focus on 5 basic aspects: 
Finding out the teacher's personal and professional characteristics and his/her influence on the use of ICT with students from the diversification program.

Describing how the teacher uses the virtual worlds.

Finding out the tasks undertaken by the students within the virtual world.

Describing the students' perception regarding the use of this learning tool.

Finding out how students assess the experience.

\subsubsection{Work procedure:}

Based on the established goals of the research, and taking as a point of reference the bibliographical review focused on the study of academic failure, virtual worlds, learning communities (references that make up an important part of what is described in section 2), and certain texts for the analysis of good practices (Escudero, 2009a; Doyle, 1985; Mishra \& Koehler, 2006; Castañeda, 2011), a series of analytical tables were created to fulfill three fundamental functions in the development of the study: (1) they served as a starting point for our research, (2) they were the foundation for the creation of each of the instruments used, and (3) as a pillar for categorizing the information obtained with each of those instruments. The summary of said tables can be seen in the following illustrations.

The following chart shows the strategies undertaken to collect data, as well as the instruments and information sources that have aided us in carrying out the analysis presented below.

Table 1. Methodology, instruments and sources.

\begin{tabular}{|c|c|c|c|}
\hline $\begin{array}{c}\text { Method- } \\
\text { ology }\end{array}$ & Instruments & $\begin{array}{l}\mathrm{CO} \\
\mathrm{DE} \\
\end{array}$ & Sources \\
\hline \multirow[t]{4}{*}{$\begin{array}{l}\text { Case } \\
\text { Studies }\end{array}$} & $\begin{array}{l}\text { 1. Documentary } \\
\text { analysis }\end{array}$ & DA & $\begin{array}{l}\text { Documentation from the } \\
\text { Espurna project } \\
\text { Legislative documentation }\end{array}$ \\
\hline & $\begin{array}{l}\text { 2.Direct observa- } \\
\text { tion }\end{array}$ & DO & $\begin{array}{l}\text { Espurnik (virtual class- } \\
\text { room) }\end{array}$ \\
\hline & $\begin{array}{l}\text { 3. Semi-structured } \\
\text { interview }\end{array}$ & TI & Teacher \\
\hline & 4. Group interview & SI & Students \\
\hline
\end{tabular}

With this data collected, an analysis based on categories was carried out, allowing for an in-depth view of the experience.

In order to analyze all of the collected information, a category system was designed, starting with the codification of the instruments. Subsequently, different labels were assigned to each of the categories designed previously from the work done in the first part of the research, with tables for hubs of interest. These labels were made up of letters corresponding to the large category blocks and numbers assigned to the subcategories.

Table 2. System of categories for the collection and classification of the data

\begin{tabular}{llll}
\hline \multicolumn{1}{c}{ Categories } & Codes & \multicolumn{1}{c}{ Categories2 } & Codes3 \\
\hline $\begin{array}{l}\text { Open Classroom Pro- } \\
\text { gram }\end{array}$ & OC & $\begin{array}{l}\text { Curriculum; contents, } \\
\text { intended learnings and } \\
\text { teaching methodologies }\end{array}$ & CURR \\
\hline $\begin{array}{l}\text { Official design of the } \\
\text { program. }\end{array}$ & 1 & $\begin{array}{l}\text { Learnings developed in } \\
\text { the classroom }\end{array}$ & 1 \\
\hline Resources available. & 2 & Methodologies employed & 2 \\
\hline $\begin{array}{l}\text { Assessment of the } \\
\text { program by the center }\end{array}$ & 3 & $\begin{array}{l}\text { Use of educational re- } \\
\text { sources }\end{array}$ & 3 \\
\hline
\end{tabular}

\begin{tabular}{|c|c|c|c|}
\hline Espurna Project & EP & $\begin{array}{l}\text { Content selection and } \\
\text { organization }\end{array}$ & 4 \\
\hline $\begin{array}{l}\text { Official design of the } \\
\text { project }\end{array}$ & 1 & $\begin{array}{l}\text { Conceptual relevance of } \\
\text { the contents }\end{array}$ & 5 \\
\hline Resources available & 2 & Type of contents & 6 \\
\hline $\begin{array}{l}\text { Assessment of the } \\
\text { Espurna project }\end{array}$ & 3 & $\begin{array}{l}\text { Quality of cognitive } \\
\text { operations }\end{array}$ & 7 \\
\hline $\begin{array}{l}\text { Administration Involve- } \\
\text { ment }\end{array}$ & 4 & $\begin{array}{l}\text { Use of diverse forms of } \\
\text { representation and differ- } \\
\text { ent codes }\end{array}$ & 8 \\
\hline Context & CTX & Evaluation of learnings & 9 \\
\hline $\begin{array}{l}\text { Principal characteristics } \\
\text { of the context of the } \\
\text { center }\end{array}$ & 1 & $\begin{array}{l}\text { Recognition, assessment } \\
\text { and attention to diversity }\end{array}$ & ADIV \\
\hline $\begin{array}{l}\text { Principal characteristics } \\
\text { of IES Cal Gravat }\end{array}$ & 2 & $\begin{array}{l}\text { Variety of teaching strate- } \\
\text { gies }\end{array}$ & 1 \\
\hline Target Student Body & SB & $\begin{array}{l}\text { Use of alternative forms of } \\
\text { representation and expres- } \\
\text { sion of knowledge }\end{array}$ & 2 \\
\hline Academic trajectory & 1 & Personalized goals & 3 \\
\hline $\begin{array}{l}\text { Objective data of the } \\
\text { student body }\end{array}$ & 2 & $\begin{array}{l}\text { Classroom atmosphere; } \\
\text { support, demand, and } \\
\text { care relations }\end{array}$ & Атмо \\
\hline $\begin{array}{l}\text { Aspirations, abilities, } \\
\text { attitudes towards school, } \\
\text { interests, expectations }\end{array}$ & 3 & $\begin{array}{l}\text { Teacher - students, stu- } \\
\text { dents - teacher relation- } \\
\text { ship }\end{array}$ & 1 \\
\hline $\begin{array}{l}\text { Family and social envi- } \\
\text { ronment }\end{array}$ & 4 & $\begin{array}{l}\text { Use of personalized } \\
\text { tutoring sessions, conflict } \\
\text { resolution methods, } \\
\text { classroom rules, personal- } \\
\text { ized goals, high learning } \\
\text { expectations }\end{array}$ & 2 \\
\hline $\begin{array}{l}\text { Digital competency, } \\
\text { access to technology, } \\
\text { attitude towards technol- } \\
\text { ogy }\end{array}$ & 5 & $\begin{array}{l}\text { Student attendance, in- } \\
\text { volvement and learning }\end{array}$ & 3 \\
\hline Teacher & TCH & Space-time structures & STR \\
\hline $\begin{array}{l}\text { Objective data of the } \\
\text { teacher }\end{array}$ & 1 & Classroom organization & 1 \\
\hline $\begin{array}{l}\text { Beliefs, motivations, } \\
\text { concept of education, } \\
\text { involvement in the } \\
\text { program, theoretical } \\
\text { budgets and general } \\
\text { conceptions }\end{array}$ & 2 & Time management & 2 \\
\hline $\begin{array}{l}\text { Knowledge of the cur- } \\
\text { ricular content }\end{array}$ & 3 & $\begin{array}{l}\text { Place and assessment of } \\
\text { Espurnik within the } \\
\text { center and the classroom }\end{array}$ & ESK \\
\hline $\begin{array}{l}\text { Knowledge of the peda- } \\
\text { gogy }\end{array}$ & 4 & $\begin{array}{l}\text { Integration of Espurnik } \\
\text { into the life of the class- } \\
\text { room. }\end{array}$ & 1 \\
\hline $\begin{array}{l}\text { Knowledge of the tech- } \\
\text { nology }\end{array}$ & 5 & $\begin{array}{l}\text { Integration of Espurnik } \\
\text { into the life of the center }\end{array}$ & 2 \\
\hline $\begin{array}{l}\text { Alliances and networks } \\
\text { of family, community } \\
\text { and social support }\end{array}$ & NET & $\begin{array}{l}\text { Levels and subjects in- } \\
\text { volved in Espurnik }\end{array}$ & 3 \\
\hline $\begin{array}{l}\text { Network of relations } \\
\text { created by the project } \\
\text { (families, other agents, } \\
\text { other students, institu- } \\
\text { tions...) }\end{array}$ & 1 & $\begin{array}{l}\text { Previous preparation of } \\
\text { the teaching staff, availa- } \\
\text { ble resources, trajectory } \\
\text { and institutional or teach- } \\
\text { ing achievements }\end{array}$ & 4 \\
\hline $\begin{array}{l}\text { Articulation of the } \\
\text { shared responsibilities } \\
\text { regarding the intellectu- } \\
\text { al, personal and social } \\
\text { development of the } \\
\text { students }\end{array}$ & 2 & $\begin{array}{l}\text { Program evaluation (use- } \\
\text { fulness, participants, type, } \\
\text { method, evaluating sub- } \\
\text { ject) }\end{array}$ & 5 \\
\hline $\begin{array}{l}\text { Coordination, review } \\
\text { and evaluation spaces }\end{array}$ & 3 & & \\
\hline
\end{tabular}

The organization of the information for subsequent analysis began with data reduction, the search for the dimensions in the 
material, their classification in the corresponding category, and their codification (Miles \& Huberman, 1984). In this way, a series of fragments sharing a common denominator was obtained, which facilitated the handling and subsequent analysis of the compiled information.

\section{RESULTS}

The aim of this text is to put special emphasis on how the use of technologies is implemented in the reality of teaching for this diversification classroom. For this reason, only the results relative to certain aspects that are decidedly involved in said implementation are presented below, with the understanding that other aspects of context, legislation, and professional development must be included in other analyses.

\subsection{Context}

The experience took place in a newly created center, where the principal was able at the time to select a significant part of his/her teaching team (DA-CTX-2), an aspect that had a big influence on the high level of commitment to the functioning dynamic of the center. Its low number of students (350) and teachers (32) also facilitated the development of a family dynamic and of closeness among the entire educational community (TI-CTX-2) (SI-CTX-2).

The center is highly committed to innovation (DA-CTX-2), participating since its beginnings in the Educat $1 \times 1$ project and the Escuela 2.0 project. It also has a virtual learning environment (MOODLE), web page, participation in the Espurna project, a Tutorial Action Plan, and participates in two city hall projects.

\subsection{Attention to diversity}

It is important for the center work with a more limited number of students in both the open classrooms and the flexible groups (another attention to diversity measure), and thus be able to set more personalized goals for the learning needs of each student (DA/TI-ADIV-3).

It is clear to management, the attention to diversity department, and the teachers who work directly with the students that it is necessary to work with personalized goals and to develop personalized study plans for each one (TI/DA-ADIV-2). The students interviewed that belong to an open classroom declare that they feel more heard (SI-ADIV-2).

The vision of education shared by the entire teaching team, as an educational community, has contributed to the need to apply real changes to the work methodologies inside the classrooms, especially in the open classroom, more than the development of the specific programs to attend to diversity. This is the view on education shared by management and the teaching staff itself (DA/TI-ADIV-1) (TI-TCH-2).

\subsection{Open Classroom Program}

In the case of the open classroom, the students that end up in the program are carefully selected, establishing very clear selection criteria (a task performed by the attention to diversity department, management team, and the rest of the department heads so that the issues of this program do not become a minor or marginal matter in the center's dynamic (TI-OC-3)), and attempting to include more $4^{\text {th }}$-level than $3^{\text {rd }}$-level ESO students in an effort to exhaust all options within the center. The teaching staff also makes an effort to distribute the work performed by the students in the program by means of the center's various media (TI-OC-3), in order to improve the image held by the rest of their schoolmates and certain families of the open classrooms (DA-OC-3) (SI-OC3). The students that participate in the open classroom recognize that "we work hard" and that in the end "it isn't bad being in diversification because we do things differently and we learn more" (SI-OC-3). It is interesting to highlight the opinion of the teacher recognizing that in this classroom, with a smaller number of students, a maximum of 10 , they work more intensely than in other types of groupings, which translates into academic improvements: "the fact that we have fewer students, this year only 6 students, allows us to work more intensely and to be more on top of them, so they work harder and more consistently”.

The center also tries to ensure that these types of measures do not turn into a total isolation of the students, and certain courses undertake the measures in conjunction with their classmates from the regular classroom, as well as all of the field trips taken throughout the course. (TI/SI-OC-3)

The program has a series of resources outside of the center, such as occupational workshops, a theater workshop, and a body language and dance workshop. It also has an educational psychologist that works with them on issues of academic and professional orientation, as well as specific social skills (DAOC-2). These resources affect the smooth functioning of the program and the prestige it enjoys among the rest of the teaching staff, an aspect that must improve among the families and the rest of the center's students (TI/SI-OC-3).

\subsection{Target students}

The use of positive language and high expectations on the part of the teaching staff appear in some texts as indispensable guidelines for achieving a truly inclusive education (Escudero 2005). The Attention to Diversity Department is convinced of the need to always work for the students to achieve more than they themselves might expect (DA/TI-SB-3).

In terms of the attitude towards new technologies, the students are enthusiastic, especially those that do not have a computer at home. The innovative component, along with the activities they undertake with the technology, seems much more useful and fun to them: "most likely in the future everything will have to do with a computer, and this way we'll be more prepared" (SI-SB5).

\subsection{Curriculum; contents, intended learnings and teaching methodologies}

In order to fulfill the goals of the diversification classroom, there is interdisciplinary work and work by fields, using a wide variety of resources ranging from the use of occupational workshops offered by City Hall, to the theater group and the resources from the Espurna project (DA/TI-CURR-1,2,3).

The work in the classroom is done in a very structured way (DO-CURR-2), with a very clear sequence of the activities to be carried out over the course of the week. The information given to the students in order to carry out the proposed tasks is also done in a very organized manner, giving preference to simple and very precise instructions "in order not to leave any room for interpretations” (DO/TI-CURR-2). The tasks are performed both in groups and individually. The advantage of having fewer students allows the teacher to adapt the classes to the different learning rhythms, and even to prepare a single material using different forms of representation, which greatly facilitates diverse learning styles (DO/TI-CURR-8, 2).

The evaluation throughout the course is formative. Thus, a continuous dialogue is maintained with the families: “we don't 
give the grades to the students, but rather to the families" (TICURR-9). Neither are they given a standard report card throughout the course; rather, a report is made with the aspects they have improved upon, and what they need to improve in terms of the each student's personalized study plan. At the end of the course they do receive a report card like the one given in the regular classroom. This evaluation method offers the information necessary to visualize each student's individual progress, as well as to detect the specific needs of each, and to be able to work on them in time throughout the course (DO/TICURR-9).

\subsection{Space-time structures}

The open classroom is the only group that has its own space. This classroom has enough space for a group of 10 people and has the typical classroom amenities, as well as a computer and printer (DA/TI-STR-1). Since they do not switch classrooms, the open classroom students decorate their space with the work they've done, and even with photos and some posters of things they enjoy (DA-STR-1). The layout of the students in the classroom usually varies according to the needs of each activity, although the layout they like most is in a circle or positioned in an office style, "like at a newspaper" (TI-STR-1).

Working on a project-by-project basis allows the teacher to make the schedules flexible according to the needs of each task and to the learning times of each student. (DA/TI-STR-2).

\subsection{Espurna Project}

This project offers the teacher the possibility of working in collaboration with other centers involved in the project, being a learning platform (TI-EP-3). The permanent training of the teaching staff is an aspect of great importance to the education center and is one of the firm beliefs of this teacher: "if we want to improve the academic dropout numbers and the academic results of our students, it is necessary to have time to continue our own training, and the virtual learning communities are a good way of doing that” (TI-EP-3).

The assessment of the Espurna project is very positive and there is proof of that in the increased number of centers and teachers involved in the project, and the interest displayed by institutions such as the Telefónica Foundation and the invitation to participate in conferences on virtual worlds taking place in Boston (TI/DA-EP-4).

\subsection{Activity in the virtual world: Espurnik}

The virtual world in three dimensions is a large classroom within the classroom itself, although there is no specific time to use it within the students' schedule, but rather it is considered as one more tool to use depending on the goals to be reached "Espurnik is a means, not an end (...) although it must be acknowledged that it is a very powerful tool" (TI-ESK-1).

The teacher's training allows students to quickly learn to navigate within the virtual world. In addition, the in-depth knowledge he/she has of the program (having been part of the technical team since its beginnings) means that any problems having to do with access, difficulty in navigation, or of any other type can be solved quickly and effectively (DO-ESPK-4).

It is worth pointing out that at the beginning, the students themselves have the feeling that "we're not going to learn much with this" (SI-ESPK-5), although they recognize that in the end it helps them to learn "everything together at once" (SI-ESK-5). With a single task they learn how to express themselves properly, they are required to write using chat, social skills when in contact with other students from other centers, mathematics, they hang up objects, clean the spaces, become familiar with the computers, etc., as well as the goals inherent in the proposed activity.

For the students, Espurnik has become "a place where teachers and students get together to exchange ideas and learn about others, such as people from other countries who can get on Espurnik and learn a lot of Spanish and Catalan”. The biggest surprise is seeing how the majority of students use the virtual world in their free time to get to know people, and above all to help each other. Many already exchange tricks for performing complex tasks such as creating walls of different textures, or to explain the different tasks each group carries out on Espurnik. The collaboration within this space seems to have become a constant (DO/SI-ESPK-5).

Espurnik also allows the students to carry out their projects in a group from their homes, although some of the students didn't have an Internet connection, "but you can always go down to the library, where you can get a Wi-Fi connection from the benches outside" (SI-ESPK-5). This is a matter of great importance, but as we can see, the students themselves almost always find solutions, more so in a large city where wireless connection zones are more common (DO-ESPK-5)

The adaptation and learning processes for navigating Espurnik are quite fast, with the responsibility falling first to the teacher, who guides students. But it becomes a shared responsibility, since in many cases the students help each other as the course advances: "everything is easier in Espurnik, it's a matter of looking and learning, and testing buttons and things, because if you get it wrong it's no problem" (SI-ESPK-5).

Neither the methodology nor the assessment differs from those that take place in the classroom itself (DO-ESPK-5): "since it is a tool; that is, a means and not an end, we don't modify our assessment criteria, nor do we assess the students based on how they navigate the tool itself. What's really important are the activities we perform using Espurnik, and their final learnings, as well as the possibility of improving these learning processes with our students (TI-ESPK-5).

\subsection{Classroom atmosphere; support, demand, and care relations}

Due to the small number of students in the classroom, the atmosphere of said classroom is different than the atmosphere established in a regular classroom, since it allows for a closer relationship between teacher and student (SI-ATMO-1). The teaching staff also makes efforts to ensure that this group does not feel isolated and does not end up being a ghetto within the school (DA-ATMO-1). In order to do this, the students attend some courses with their classmates from the regular classroom and all of the field trips outside the center (TI-ATMO-1).

The center has an individualized tutoring plan. Each teacher, including the principal, is in charge of 10 students, with whom he/she carries out a very intensive tutoring session, and in the case of the open classroom the tutor is someone that belongs to the program; that is, they give the class. This greatly facilitates the subject of conflict resolution, and helps with early detection of problems or difficulties of any type in the student's progress (DA/TI-CURR-2).

It is important for the teacher to have strategies with which he/she is able to confront tense situations that occur on occasion in the classroom: "many students that are completely frustrated 
end up exploding, and it's easy for them to do it at the center, since they spend many hours with us" (TI-ATMO-2).

In general the students' motivation is quite high with respect to the activities proposed in the classroom, with the exception of those in which they have to write extensively. They also have a great deal of confidence in their teachers and in the tasks they propose. The teachers attempt to maintain a high level of confidence in the possibilities of each student (SI-ATMO-3) (TIATMO-1,3). The classroom rules are made by the entire group, both of teachers and of students, and subsequently communicated to the families (TI-ATMO-2).

The students openly display the affection they feel towards their teacher "because (he/she) makes a big effort to understand us and to do very cool things so that we don't get bored in class, although sometimes (he/she) goes overboard assigning us homework" (SI-ATMO-1). In this sense, the teacher also has the conviction that the students "appreciate when they see that the teacher has prepared an activity that (he/she) has worked hard on, and they see that they're learning, that motivates them as well”. Giving them the opportunity to learn in a way that's different than the one they're used to in the classrooms also fosters a good relationship between teacher and student (TIATMO-1).

\subsection{Alliances and networks of family, community, and social support}

The coordination with the families is done by means of personal interviews, and through the official participation channels that exist at the center, such as the school board and the AMPA [Asociación de Madres y Padres de Alumnos (Association of Mothers and Fathers of Students] with which a very fluid relationship is maintained (DA-NET-1).

Externally, the center has a quite extensive support network, starting with the Department of Teaching by way of the psychopedagogic teams (DA-NET-1), the neighborhood association, the theater group, and City Hall by way of social services (with a very significant collaboration due to the participation of the open classroom students in the Laboralia and El Puntal projects). This coordination is carried out through the area social educator and the diversification department (DA/TI2,3). At all times there is an effort to take advantage of outside opportunities, working project-by-project with other organizations, maintaining a constant relationship with the surroundings, which is fundamental for the open classroom students (TI-NET-2,3).

\section{CONCLUSIONS}

One of the first conclusions is about what are the "optional" condition of these types of initiatives. The teacher must be highly motivated and committed to issues of digital literacy in less privileged contexts, or in the diversification classrooms, where the minimum goals are occasionally a ceiling and not a starting point.

The interest of this teacher lies fundamentally in helping his/her open classroom students, conscious that it is a "last opportunity" in the system to achieve basic competencies and a subsequent degree, to give them the capacity for an increasingly demanding society, offer them knowledge that will be useful in their daily lives, and, without a doubt, training in the use of technologies, which is already a basic competency in our daily lives. The students themselves clearly value the opportunity to gain access to technology, because they are aware that they will have to use it tomorrow. They do not believe in the obstacles that currently exist with respect to Internet access. Those that do not have an internet connection in their home are entirely comfortable with the search for spaces with available internet access, and even public spaces that have computers with which to connect.

The use that the teacher makes of Espurnik is not final, but rather it is used to create, produce and build (collaboratively in the majority of cases) knowledge, learnings founded in interdisciplinary, which are so necessary to the daily work in the open classrooms.

It is also important to remark that the communication competencies and social abilities developed through the virtual world. It is interesting to observe the ease with which they interact, the naturalness and respect with which they begin a conversation, digital-era communication competencies that should already be in the school curriculum.

Espurnik is a novel tool that brings extra motivation to the student, but also contains the recreational component that has always been used as a resource for learning in the classroom, although more often in pre-school and primary education. This recreational component also helps the students with their socialization in this virtual learning world. It also helps with collaboration, an aspect that not only turns up in the group projects, but that transcends even the classroom group itself, appearing as a sort of unwritten rule within the virtual world.

Espurnik facilitates project-by-project work, and thereby the development of interdisciplinary learnings, which is fundamental in education and even more so in the diversification curricular programs.

Some studies assert that these types of virtual worlds improve concentration (Del Moral, 2012), since the students must pay attention to everything that occurs within the virtual space, in addition to the teacher's instructions, which occurs more frequently in the first contacts with this tool. The study does not manage to assess this aspect, although it does affirm, by direct observations in the virtual world, that quite a bit of concentration on the task is required in order to follow the steps and rhythm of the class. In this regard it is important to emphasize the function carried out by the group of students with respect to the mutual assistance they offer each other. In this way the rhythms of the class tend to be more equal.

The work methodology developed with Espurnik allows all of its students to contribute knowledge and exchange it with the rest of their classmates and even with students from other centers, making them the protagonists of their learnings and allowing them to make mistakes, from which they learn very quickly. Thus, they end up playing a much more active role.

Finally, another highlight is the extensive training of the teacher, both in terms of attention to diversity and educational technology, in addition to their extensive experience in both fields, the belief that continued training is increasingly necessary if we want to achieve true change in the educational system and in each of the classrooms at our school centers. Thus, teacher training emerges as an important aspect in the achievement of a truly inclusive school (Montesano, 2012). Active teacher participation in a learning community such as Espurna, and the use of Espurnik, favors the inclusion of its students in much broader learning contexts, forming part of something far beyond their classroom and center.

Analyzing the practices carried out in the classrooms, and especially those involving people in a situation of educational exclusion, is still very necessary today. The opportunity that ICT 
offers in providing contexts of cooperative learning, the execution of shared projects that encourage motivation, and the opportunity to learn how to learn, with attention that is much more personalized and adapted to the real needs and interests of each student, should lead investigators to an analysis of all innovative educational practices that favor the development of coherent educational responses.

The task of analyzing and publishing the results, creating the necessary connections in order to increase the number of people carrying out that necessary transformation of the classrooms, of the centers, and, in short, within the educational system, is not only the function of administrations, teachers, students and families, but it is also necessary for society as a whole to be involved in these processes of improvement (Raffo, 2009), of the necessary transformation of our educational system towards a truly inclusive school.

Achieving this ideal of inclusive education, which is the definite backdrop in these types of studies, requires the commitment of all citizens, social, political and educational agents (Escudero, 2013). In this manner we will move towards a more unifying school, built with and on diversity; In short, an inclusive school model that can respond to all of its students', and thus to our society's, needs. Although some of the measures being carried out by the EU are also the object of criticisms with respect to the neoliberal policies that result from said measures (Nguyen, 2010).

\section{REFERENCES}

Abajo, J. (2011). La situación escolar del alumnado de minorías étnicas: el modelo explicativo ecológico-cultural de Jhon Ogbu. Recerca: revista de pensament $i$ anàlisi, 11, 71-92. doi: 10.6035/recerca.2011.11.6

Antonova, A. (2013). Virtual Worlds in the Context of Competence Development and Learning. In S. Augustino (Ed.), Adaptation, Resistance and Access to Instructional Technologies: Assessing Future Trends in Education (pp. 194208). Hersey, PA: IGI Global. doi:10.4018/978-1-4666-2670-6.ch012

Barlam, R. Lasala, M. J. Marín, J. Masalles, J., \& Pinya, C. (2011). Aula de Innovación Educativa. Revista Aula de Innovación Educativa, 205, 77-78.

Bignell, S., \& Parson, V. (2010). Best practices in virtual worlds teaching. University of Derby, University of Aston and the Higher Education Academy Psychology Network. Derby: University of Derby.

Boza, A., \& Toscano, M. O. (2011). Buenas prácticas de la integración de las TIC en educación. VI Congreso Virtual de AIDIPE. Symposium conducted at the meeting of Asociación Interuniversitaria de Investigación Pedagógica (AIDIPE). Retrieved from http://www.uv.es/aidipe/congresos/Ponencia_VIICongresoVirtual_AIDIPE.pdf

Calero, J., Escardíbul, J.-O., \& Choi, Á. (2012). El fracaso escolar en la Europa mediterránea a través de PISA-2009: radiografía de una realidad latente. Revista Española de Educación Comparada, 19, 69-103. doi: 10.5944/reec.19.2012.7578

Carson, D. C., Esbensen, F., \& Taylor, T. J. (2013). A longitudinal analysis of the relationship between school victimization and student mobility. Youth Violence and Juvenile Justice, 11(4), 275-295. doi: 10.1177/1541204013477118

Castañeda, L. (2011) Analizar y entender la enseñanza flexible. Un modelo de análisis de desarrollo curricular. Píxel-Bit. Revista de Medios y Educación, 39, 167-195

Comisión Europea. (2011). Comunicación de la Comisión al Parlamento Europeo, al Consejo, al Comité Económico y Social europeo y el Comité de las Regiones. Abordar el abandono escolar prematuro: una contribución clave en la agenda Europea 2020. Retrieved from http://ec.europa.eu/education/schooleducation/doc/earlycom_es.pdf

Del Moral, E. (2012, April). Los videojuegos aceleran el aprendizaje y mejoran la concentración. La Nueva España. Retrieved from http://www.lne.es/asturama/2012/04/27/moral-videojuegos-aceleranaprendizaje-mejoran-concentracion/1233764.html?utm_source=rss

Doyle, W. (1985). La investigación sobre el contexto del aula: hacia un conocimiento básico para la práctica y la política de formación del profesorado. Revista de Educación, 277, 29-42.
Escudero, J. (2009a). Buenas prácticas y programas extraordinarios de atención al alumnado en riesgo de exclusión educativa. Profesorado: revista de currículum y formación del profesorado, 13(3), 108-141.

Escudero, J. (2009b). Comunidades docentes de aprendizaje, formación del profesorado y mejora de la educación. Ágora para la Educación física y el Deporte, 10, 7-31.

Escudero, J. González, M., \& Martínez, B. (2009). El fracaso escolar como exclusión educativa: comprensión, políticas y prácticas. Revista Iberoamericana de Educación, 50, 41-64.

Escudero, J. M. (2005). Fracaso escolar, exclusión educativa ¿de qué se excluye y cómo? Profesorado: Revista de currículum y formación del profesorado, 9(1), $2-24$.

Escudero, J. M. (2013). ¿Está fracasando la escuela como institución sociocultural? Congreso virtual WEBINAR 2013 ¿Está fracasando la escuela como institución sociocultural? Symposium conducted at the meeting of Red Universitaria de Investigación e Innovación Educativa (REUNI+D), La Laguna, Universidad de La Laguna.

Fernández, M. (2010). Fracaso y Abandono escolar en España. Barcelona: Fundación La Caixa.

Field, S., Pont, B., \& Kuczera, M. (2007). No More Failures. In Education and Training Policy. Paris: OCDE. doi:10.1787/9789264032606-en

García, M., \& Cotrina, M. (2004). Descubriendo el valor de las tecnologías de la información y la comunicación en la atención a la diversidad. TAVIRA. Revista de Ciencias de la Educación, 20, 107-121.

García, M., \& López, R. (2012). Explorando, desde una perspectiva inclusiva, el uso de las TIC para atender a la diversidad. Profesorado. Revista de currículum y formación del profesorado, 16(1), 278-293.

González, M., \& Porto, M. (2011). Programas y medidas contra el abandono escolar en la enseñanza obligatoria: análisis comparativo entre España y Argentina. IN IV Congreso Nacional / III Encuentro Internacional de Estudios Comparados en Educación “¿Hacia dónde va la educación en la Argentina y en América Latina? Construyendo una nueva agenda”. Symposium conducted at the meeting of Sociedad Argentina de Estudios Comparados (SAECE), Buenos Aires.

Hill, A. J. (2014). The costs of failure: Negative externalities in high school course repetition. Economics of Education Review, 43, 91-105. doi: http:10.1016/j.econedurev.2014.10.002

Koetting, J. R. (1984). Foundations of Naturalistic Inquiry: Developing a Theory Base for Understanding Individual Interpretations of Reality. Oklahoma: University Press.

Koh, J. H. L., \& Chai, C. S. (2014). Teacher clusters and their perceptions of technological pedagogical content knowledge (TPACK) development through ICT lesson design. Computers and Education, 70, 222-232. doi: 10.1016/j.compedu.2013.08.017

Krajka, J., \& Kleban, M. (2014). E-training in practical teacher development - from local to global connections. International Journal of Continuing Engineering Education and Life-Long Learning, 24(1), 96-106. doi:10.1504/IJCEELL.2014.059337

Lingard, B., Hayes, D., \& Mills, M. (2003). Teachers and productive pedagogies: contextualising, conceptualising, utilising. Pedagogy, Culture \& Society, 11(3), 399-424. doi:10.1080/14681360300200181

Marchesi, A. (2003). El fracaso escolar en España. Madrid: Fundación Alternativas.

Martínez, F., \& Prendes, M. (2004). Presentación. In F. Martínez, \& M. Prendes (Coords.), Nuevas tecnologías y educación. Madrid: Pearson Prentice Hall.

Martínez, J. S. (2009). Fracaso escolar, PISA y la difícil ESO. RASE: revista de la Asociación de Sociología de la Educación, 2(1), 56-85.

MCkinney, S. Horspool, A. Safie, O., \& Richin, L. (2009). Using second Life with learning-disabled students in Higher Education. INNOVATE: Journal of online education, 5(2).

Merrian, S. (1988). Case study research in education. San Francisco: Jossey-Bass.

Miles, M., \& Huberman, M. (1984). Qualitative data analysis. A sourcebook of new methos. London: Sage Publications.

Mishra, P., \& Koehler, M.(2006). Technological, Pedagogical Content Knowledge. Teachers College Record, 108(6), 1017-1054. doi:10.1111/j.14679620.2006.00684.x

Montesano, N. (2012). Improving the context for inclusion: personalising teacher development through collaborative action research. Educational Action Research, 20(4), 623-624. doi:10.1080/09650792.2012.727661

Nachmias, R., Mioduser, D., Cohen, A., Tubin, D., \& Forkosh-Baruch, A. (2004). Factors Involved in the Implementation of Pedagogical Innovations Using Technology. Education and Information Technologies, 9(3), 291-308. doi:10.1023/B:EAIT.0000042045.12692.49

Navarrete, L. (2007). Jóvenes y fracaso escolar en España. Madrid: Injuve. 
Nguyen, T. X. T. (2010). Deconstructing Education for All: discourse, power and the politics of inclusion . International Journal of Inclusive Education, 14(4), 341-355. doi:10.1080/13603110802504564

Raffo, C., Dyson, A., Gunter, H., Hall, D., Jones, L., \& Kalambouka, A. (2009). Education and poverty: mapping the terrain and making the links to educational policy. International Journal of Inclusive Education, 13(4), 341358. doi:10.1080/13603110802124462

Reynolds, J. (2010, 29 November). Fracaso escolar, un reto a encarar desde múltiples frentes. Retrieved from

http://www.educaweb.com/noticia/2010/11/29/fracaso-escolar-reto-encararmultiples-frentes-4489/

Rodríguez-Mena, M., \& García, I. (2003). El aprendizaje para el cambio. Papel de la educación. CONVERGENCIA; Revista de Ciencias Sociales , 10 (32), 317335.

Silins, H., Zarinas, S., \& Mulford, B. (2002). What characteristics and processes define a school as a learning organization? International Educat journal, 3(1), 24-33.

Sola, M., \& Murillo, J. (2011). Las TIC en la Educación. Realidad y Expectativas. Fundación Telefónica. Barcelona: Ariel.

Spruyt, B. (2014). Talent, effort or social background?: An empirical assessment of popular explanations for educational outcomes. European Societies. doi:10.1080/14616696.2014.977323

Stake, (1995). The art of case study research. Thousand Oaks. CA: Sage Publications.

Stoll, L., \& Louis, K. S. (Ed.). (2007). Professional Learning Communities: divergence, Depth and Dilemas. Mandenhead: Open University Press.

Van Braak, J. (2001). Factors influencing the use of computers mediated communication by teachers in secondary education. Computers and Education, 36, 41-57. doi:10.5539/hes.v2n2p125

Walkey, F. H., McClure, J., Meyer, L. H., \& Weir, K. F. (2013). Low expectations equal no expectations: Aspirations, motivation, and achievement in secondary school. Contemporary Educational Psychology, 38(4), 306-315. doi:10.1016/j.cedpsych.2013.06.004

Wang, S., \& Hsu, H. (2009). Using the ADDIE Model to Desing Second Life. Activities for Online Learners, 53(6), 76-81. doi: 10.1007/s11528-009-0347-x

Yin, R. (1994). Case study research: design and methods. Thousands Oaks: Sage Publications.

\section{NOTES}

\footnotetext{
${ }^{\mathrm{i}}$ The aim of curricular diversification programs is for students, by means of a specific methodology using certain contents, practical activities and materials different from the ones established, to achieve the general goals of the compulsory secondary Education stage, and, thereby, to obtain the Compulsory Secondary Education Graduate diploma.
} 